\title{
SEXUAL DIMORPHISM AND ESTIMATION OF STATURE FROM FOOT ANTHROPOMETRY FOR PERSONAL IDENTIFICATION IN 300 ADULTS OF HILLY AREAS OF HIMACHAL PRADESH
}

\author{
Archana Goel ${ }^{* 1}$, Sunil Kumar ${ }^{2}$, Nidhi Puri ${ }^{3}$. \\ ${ }^{*}$ Associate Professor, Department of Anatomy, MMIMSR Mullana, Ambala, Haryana, India. \\ ${ }^{2}$ Msc Student, Department of Anatomy, MMIMSR Mullana, Ambala, Haryana, India. \\ ${ }^{3}$ Professor \& head, Department of Anatomy, MMIMSR Mullana, Ambala, Haryana, India.
}

\section{ABSTRACT}

Background: Sexual dimorphism and estimation of stature from various measurements of the body is of value in anthropology as well as for forensic sciences for personal identification or medico legal purposes. The present study dealt to find out sexual dimorphism, correlation between stature, foot length and foot breadth and developing a regression equation for stature estimation from foot length and foot breadth.

Materials and Methods: Study was done on 150 males and 150 females of hilly areas of Himachal Pradesh. Age group ranged between 21-35 years. Foot length and Foot breadth of both the feet were measured by osteometric board and height was measured by flexible measuring tape.

Results: In males mean and S.D. of right foot length and right foot breadth are $24.80 \pm 2.10$ and $8.57 \pm 0.68$ respectively while mean and S.D. of left foot length and left foot breadth are $24.71 \pm 2.08$ and $8.55 \pm 0.67$. In females mean and S.D. of right foot length and breadth are $22.98 \pm 2.03$ and $8.03 \pm 0.67$. While mean and S.D. of left foot length and breadth are $22.86 \pm 1.98$ and $7.99 \pm 0.63$. Mean height in males is $168.83 \pm 6.20$ while in females it is $163.54 \pm 5.17$. All the measurements were measured in $\mathrm{cm}$. Foot index obtained showed higher value for females than males.

Conclusion: It is concluded that foot dimensions and height were significantly more in males. Significant correlation was found between foot dimensions and stature in both the sexes. Present study provided the regression equations to estimate stature from the foot dimensions among the Hilly area population of Himachal Pradesh. It would be unwise to use the same equations for stature estimation for different Indian populations.

KEY WORDS: Foot Dimensions, Stature, Hilly Area, Sexual Dimorphism, Personal Identification.

Address for Correspondence: Dr Archana Goel, Associate Professor, Department of Anatomy, MMIMSR Mullana, Ambala, Haryana, India. E-Mail: archanagoel23@yahoo.in

\section{Access this Article online}

\section{Quick Response code}

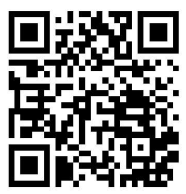

DOI: $10.16965 /$ ijar.2017.420

Web site: International Journal of Anatomy and Research ISSN 2321-4287

www.ijmhr.org/ijar.htm

Received: 16 Aug 2017

Peer Review: 16 Aug 2017

Revised: None
Accepted: 03 Oct 2017

Published (O): 01 Nov 2017

Published (P): 01 Nov 2017

\section{INTRODUCTION}

Anthropometry is an art to evaluate various human body parameters which establish the bodily geometry and uniqueness of an individual. In other words it is a basic tool for biological anthropology. Relationship between height and various parts of the body has been of great interest to biological anthropologists and forensic experts. Because stature from feet dimensions plays a significant role in establishing personal identity. This knowledge also provides insight into various features of a population including nutrition, health, environmental and genetic factors. Now a days increasing 
frequency of natural mass disasters like earthquake, tsunamis, road and train accidents, air plane crashes and man made disasters like wars, murders etc. requires special considerations where bodies are found in fragmented states beyond investigations. In such types of disasters it is very common to find the parts of body such as hand and foot. In such situations their anthropometric measurements provide good approximation about the height and sex of a person [1]. There has been sufficient studies across the world that has been done on estimation of stature from foot parameters. In India also there is lot of emphasized data available on estimating stature from foot dimensions. But in North India to be more precisely in Himachal Pradesh no such study has been done earlier to estimate stature from foot parameters. So this study is an effort to correlate stature with various anthropometric parameters of foot and to estimate height from these measurements by the use of regression analysis in the population of Himachal Pradesh.

\section{MATERIALS AND METHODS}

300 subjects of ( 150 males and 150 females) of Hilly areas of Himachal Pradesh of age group 21-35 years were taken. Prior Informed written consent for the study was obtained from all the subjects both in English and in Vernacular. Cases with foot anomalies, trauma, inflammations and surgery (if any) were excluded because of their unsuitability for the investigation. Osteometric board (figure 1a,1b) was used to measure foot length and foot breadth in centimeter $(\mathrm{cm})$. Flexible metallic measuring tape was used to measure height in centimeter $(\mathrm{cm})$.

Height - Height was the vertical distance between the point vertex (highest point on the head) when the head is held in the Frankfurt's Horizontal plane (obtained by joining infra orbital margin to the upper margin of external acoustic meatus) and the heel touching the floor (ground surface). Foot Length - (Fig 1a) Foot length was taken as a straight distance between the most posteriorly projecting points of heel (pternion) to the most anterior projecting point (Acropodion) of the first or second toe whichever was bigger when the foot was fully stretched. Foot Breadth- (Fig 1b) The foot breadth was measured as a straight distance from metatarsaletibiale (the most medially placed point on the head of first metatarsal) and metatarsalefibulare (the most laterally placed point on the head of the fifth metatarsal) when the foot was fully stretched. After taking all these measurements we have calculated foot index.

\section{Foot index $=$ Foot breadth $\times 100$ Foot length}

The data obtained were computed and analyzed using Statistical Package for Social Sciences (SPSS version 24).

\section{RESULTS}

In the present study anthropometric measurements were carried on 150 males and 150 females from hilly areas of Himachal Pradesh. Anthropometric measurements were taken, and the result of the study was tabulated and subjected to statistical computation and findings have been presented. Table 1 shows a comparison between the foot length and foot breadth of male and female residents belonging to Hilly Areas of Himachal Pradesh. On comparing foot length, foot breadth and height among two groups, we found that all these parameters were significantly $(p<0.0001)$ higher in males. In both males and in females mean right foot length and right foot breadth found to be higher as compared to left foot length and left foot breadth. Mean values of foot index of both right and left foot in female residents were found to be slightly higher [Table 2] as compared to male residents.

All the right and left foot parameters (foot length and foot breadth) were significantly $(<0.001)$ correlated to height in both the sexes [Table 3]. This correlation indicates that foot parameters provide highest reliability and accuracy in estimating stature of an unknown individual.

Parameters which were highly correlated to each other, for those we have applied linear regression equation. From that equation we have calculated certain regression formulae. Table 4 shows various regression formulae for estimation of stature in male and female residents of Hilly Areas of Himachal Pradesh. From these formulae, if we know the value of one parameter (independent variable), we can calculate the value of other parameter (dependent variable). 
Fig. 1a: Measurements of Foot Length.

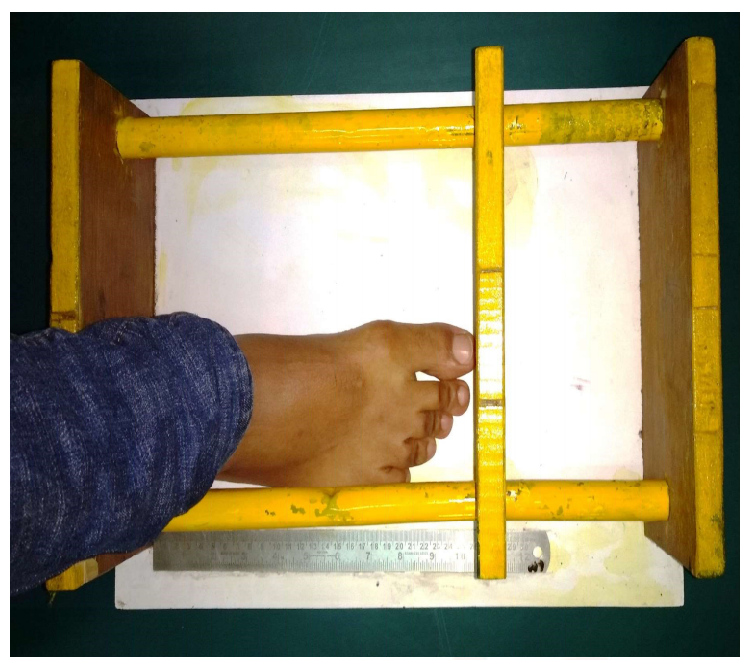

Fig. 1b: Measurements of Foot Breadth.

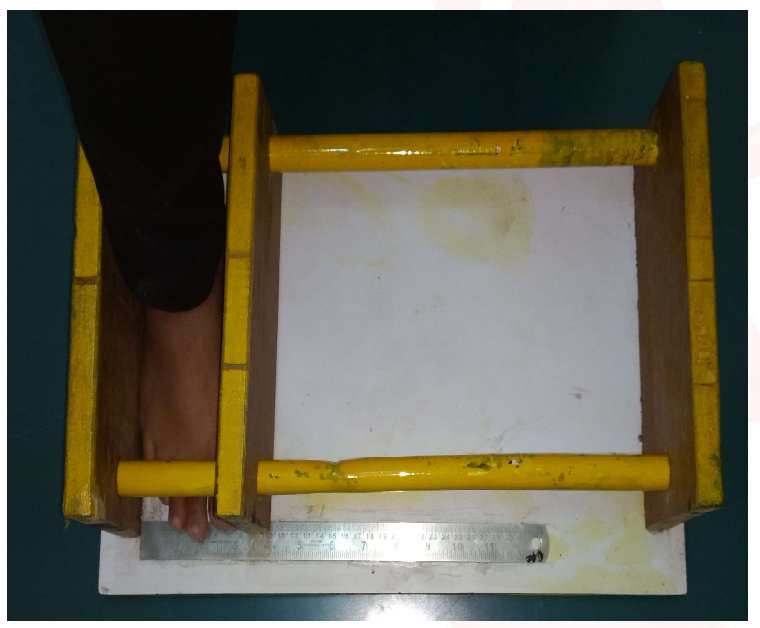

DISCUSSION

The present study was carried out to determine the sexual dimorphism in the foot dimension among adults of hilly areas of Himachal Pradesh, to provide base line data for population, for design and manufacture of shoes for correct shoe fit. In addition to this for prediction of stature from foot measurements.

Table 5 shows comparison of foot breadth and foot length of males of present study of Hilly Areas of Himachal Pradesh with the males of previous studies $[2,3,4,5]$ done on different population (Nigerian, Delhi, Haryanvi Jats, Rajasthani Jats, Uttar Pradesh). We found the mean values in present study males were significantly $(p<0.0001)$ less than the mean values of previous studies males in all parameters except Right foot breadth which showed non significant relation with previous study done by Rani et al[3] on delhi population. This might be due to that study done by Rani et al [3] was on students of different regions studied in Delhi.
Similarly on comparison of foot length and foot breadth in the females of Hilly Areas of Himachal Pradesh of present study with the previous studies $[2,3,4,5]$ those were carried out on different population (Nigerian, Delhi, Haryanvi Jats, Rajasthani Jats, Uttar Pradesh). We found significant difference $(p<0.0001)$ in all parameters except Right and Left foot length with females of North Indian mixed population[4] and females of Uttar Pradesh [5]. (Table 6) The climatic conditions also affects the size of limbs. People living in warm climates would have longer upper limbs as well as lower limbs than cold climates. Because larger foot dimensions are an adaptation to this environment because it increases surface area available for heat loss [6]. Significant differences of all parameters with Nigerian Population by Manuel I et al [2] showed racial differences. This knowledge is helpful in providing base line data for hilly area population belonged to Himachal Pradesh.

Present study males have longer and broader feet than females for a given stature and the difference is statistically significant (0.001) as shown in table 1 . This coincided with the previous studies done on different population [2-5]. These significant differences may be attributed to the early maturity of girls than boys; consequently, the boys have two more years of puberty which gave them extra time for growth. An attempt was association of $Y$ chromosomes with stature also. This may be attributed to the fact that foot is anatomically involved in the stature of a person. $[7,8]$ This showed sexual differences in foot dimensions and height which is important for personal identification. Present study revealed that right foot dimensions were larger than left foot dimensions in both males and females. This coincided with the previous studies done on population of Nigeria, Haryanvi jats, North India and Uttar Pradesh [2,4,5] .

Foot index denotes the foot shape. In present study the proportion of broad and longer feet was higher in females [table 2]. This coincided with the study done by Manuel I et al [2] on Nigerian population. This suggested that the shape of female feet is slender.

Foot dimensions were strongly correlated with height [table 3]. Thus giving better prediction of stature. Meena MC et al [9] revealed that 
there are lot of variations in estimating stature from limb measurements among people of different region and race. As the stature is inherent characteristics of the individual, though influenced environmentally, regression equation can be of great value [table 4]. So, present study coincides with the fact of Meena MC et al [9] study. we have calculated regression equations by linear regression method.

Present studies can be successively utilized in forensic examination of foot for personal identification. These finding may also be helpful in both shoe design as well in selection of shoe size. Study also verified that one can try shoe on right side first to consider how it will fit.[2]

\section{CONCLUSION}

Male feet are longer and broader than females of hilly areas of Himachal Pradesh. Right foot dimensions are more than left foot dimensions. Female feet are slender in shape. Mean values of height in males is more than females. All the foot dimensions show positive correlation with the height. From these correlated values we can calculate regression equation to estimate stature from the feet dimensions among the Hilly area population of Himachal Pradesh. It would be unwise to use the same equations for stature estimation for different Indian populations. In addition to this present study shows sexual dimorphism which is very useful in Forensic science for personal identification.

\section{ABBREVIATIONS}

$\mathrm{Cm}$ - centimeter

\section{ACKNOWLEDGEMENTS}

We must thank to the study subjects for their participation in the study.

\section{Conflicts of Interests: None}

\section{REFERENCES}

[1]. Zeybek G, Ergur I, Demiroglu Z. Stature and gender estimation using foot measurements. Forensic Sci Int. 2008;181(1-3):54.e1-54.e5

[2]. Manual I, Didia B. Sexual dimorphism in foot dimensions among adult Nigerians. The Int J Bio Anthropol. 2008;3:1-6.

[3]. Rani M, Tyagi AK, Ranga VK, Rani Y, Murari A. Stature estimation from foot dimensions. J Punjab Acad Forensic Med Toxicol. 2011;11(1):26-30.

[4]. Singla R, Bedi M, Biswas M. Sex estimation from foot anthropometry in Haryanvi jats and North Indian mixed population. J Punjab Acad Forensic Med Toxicol. 2012;12(1):13-6.

[5]. Rai R, Shrestha S. Predictive role of foot dimensions (foot length and foot breadth). Int J Basic Med Clinical Res. 2014;1(4):84-91.

[6]. Scherider E. Ecology rules and body heat regulation in man. Nature. 1975;179:915-16

[7]. Jakhar JK, Pal V, Paliwal PK. Estimation of height from measurements of foot length in Haryana region. J Ind Acad Med. 2008;32(3):231-3.

[8]. EL-Din A, Kholy S. Prediction of stature based on foot dimensions among the living Egyptians. Egyptians J Forensic Med. and Clin. Toxicol. 2009;9(2):75-86

[9]. Singh JP, Meena MC, Rani Y, Sharma G. Stature estimation from the dimensions of foot in females. Antrocom Online J Anthropol. 2013;9(2):237-41.

How to cite this article:

Archana Goel, Sunil Kumar, Nidhi Puri. SEXUAL DIMORPHISM AND ESTIMATION OF STATURE FROM FOOT ANTHROPOMETRY FOR PERSONAL IDENTIFICATION IN 300 ADULTS OF HILLY AREAS OF HIMACHAL PRADESH. Int J Anat Res 2017;5(4.2):4616-4619. DOI: 10.16965/ijar.2017.420 